\title{
DILEMMAS RELATED TO POTENTIAL CHANGES IN THE TAXATION OF FARMS
}

\section{DYLEMATY ZWIAZANE Z EWENTUALNYMI ZMIANAMI W OPODATKOWANIU GOSPODARSTW ROLNYCH}

https://doi.org/10.34739/zn.2020.51.01

\section{Marian Grzegorz Podstawka}

Poland, Institute of Agricultural and Food Economics - National Research Institute ORCID: 0000-0002-3834-0743; e-mail: marian.podstawka@ierigz.waw.pl

\begin{abstract}
Polish farms are burdened with the following taxes: agricultural tax, forestry tax, property tax, motor vehicle tax, VAT, and excise tax. The research presented here shows that small farms suffered losses in the years 2014-2018. However, income made by small farms (income of EUR 8,000 to 25,000) was burdened with taxes ranging from $29.9 \%$ in 2014 to $67.05 \%$ in total. In 2018, middle-sized farms with income between EUR 50,000 and EUR 100,000 had a share of all taxes in their income of about $4-6 \%$. Very large farms (>EUR 500,000 of income) had a symbolic tax burden of ca. $1 \%$. In the case of the tax burden on farm revenues, very small and small farms found themselves in the worst situation, similarly as before. They recorded ca. $2.7 \%$ of taxes in their revenues. The medium-sized farms had a burden of ca. $1 \%$ of their revenues with all taxes. By contrast, the revenues of very large farms were burdened with symbolic taxes in the amount of ca. $0.2 \%$. In this situation, while maintaining the current tax burden borne by farms, it should be remembered that the income tax rate and the revenue tax rate cannot exceed $5 \%$ and ca. $1 \%$, respectively.
\end{abstract}

Keywords: tax burdens, farms, income, revenue

\begin{abstract}
Streszczenie: Gospodarstwa rolne w naszym kraju obciążone są: podatkiem rolnym, podatkiem leśnym, podatkiem od nieruchomości, podatkiem od środków transportowych, a także podatkiem VAT i akcyzowym. W wyniku przeprowadzonych badań stwierdzono, że gospodarstwa małe w latach 2014-2018 osiągały straty. Natomiast dochody gospodarstw małych (8-25 tys. EUR dochodów) obciążone były łącznie wszystkimi podatkami w wysokości od $29,9 \%$ w 2014 r. do 67,05\%. W 2018 r. gospodarstwa średnie realizujące dochody w granicach 50-100 tys. EUR, miały udział wszystkich podatków w ich dochodach, na poziomie ok. 4-6\%. Gospodarstwa bardzo duże (>500 tys. EUR dochodów) ponosiły ciężar podatkowy w symbolicznej wysokości tj. ok. 1\%. W przypadku obciążenia przychodów gospodarstw podatkami, to w najgorszej sytuacji, podobnie jak poprzednio, znalazły się gospodarstwa bardzo małe i małe. Zanotowano wśród nich ok. 2,7\% podatków w przychodach. Gospodarstwa średnie miały obciążenia w wysokości ok. 1\% przychodów wszystkimi podatkami. Natomiast przychody gospodarstw bardzo dużych obciążone były podatkami symbolicznymi w wysokości ok. 0,2\%. W tej sytuacji, zachowując dotychczasowy ciężar podatkowy ponoszony przez gospodarstwa rolne, należy pamiętać, iż stawka podatku dochodowego nie może przekroczyć 5\%, a podatku przychodowego ok. $1 \%$.
\end{abstract}

Słowa kluczowe: obciążenia podatkowe, gospodarstwa rolne, dochody, przychody

\section{Introduction}

Agricultural production is characterised by many peculiarities of a natural, biological and economic nature. These two natures intertwine with each other. The natural and biological conditions have an impact on the economic nature of agricultural production, and thus on its results. The economic results of agricultural production depend, on the one hand, on the organisational and production skills of a producer and, on the other hand, on natural and soil conditions. The latter is beyond the control of producers. Therefore, taxation policy should cover these conditions. In the case of property taxes, such as those applicable in Poland, the current agricultural land tax covers the impact of the differential rent type 1 (Ricardo, 1913, ed. 2, p. 125). Its structural elements allow for a reduction of the impact of the differential rent. The basis for the agricultural tax assessment is the economic value of the land, i.e. its ability to generate income. It is expressed by conversion factors which may vary and depend on the quality class of soil, its type and location in one of four tax districts. The tax districts 
have been delimited taking into account the area of municipality and its valorised soils, water relations, agroclimate and landform features.

When we tax the income from a farm, its amount is also shaped by the differential rent type 1 . Therefore, taxation of income from a farm is a complex solution, because its size is determined not only by natural and soil conditions, but also by the intensity of production, its organisation, management and marketing skills of agricultural producers, etc.

The specificity of agricultural production is a reason for which farms make use of certain tax preferences. This is not only the case in Poland, but also in other EU countries. In the EU countries, these preferences apply to income tax and property taxes. In Poland, agricultural activities are not subject to income tax. Farms are burdened with agricultural tax, forestry and property tax, as well as VAT and excise taxes. More and more often, we can hear opinions that Polish agriculture should be taxed with income tax, just like other economic activities. We can even subscribe to these views. However, it is worth recognising the current situation pertaining to the taxation of farms. And against its background, new solutions could be proposed, bearing in mind the maintenance of the burdening of farm income at a level comparable to the present one.

\section{Literature review}

The study presented here made recourse to data from the Polish FADN (Floriańczyk, Z. et al. 2018; 2017 Standard Results of Polish FADN Agricultural Holdings, Part 1 Standard Results. Warsaw: IAFENRI).

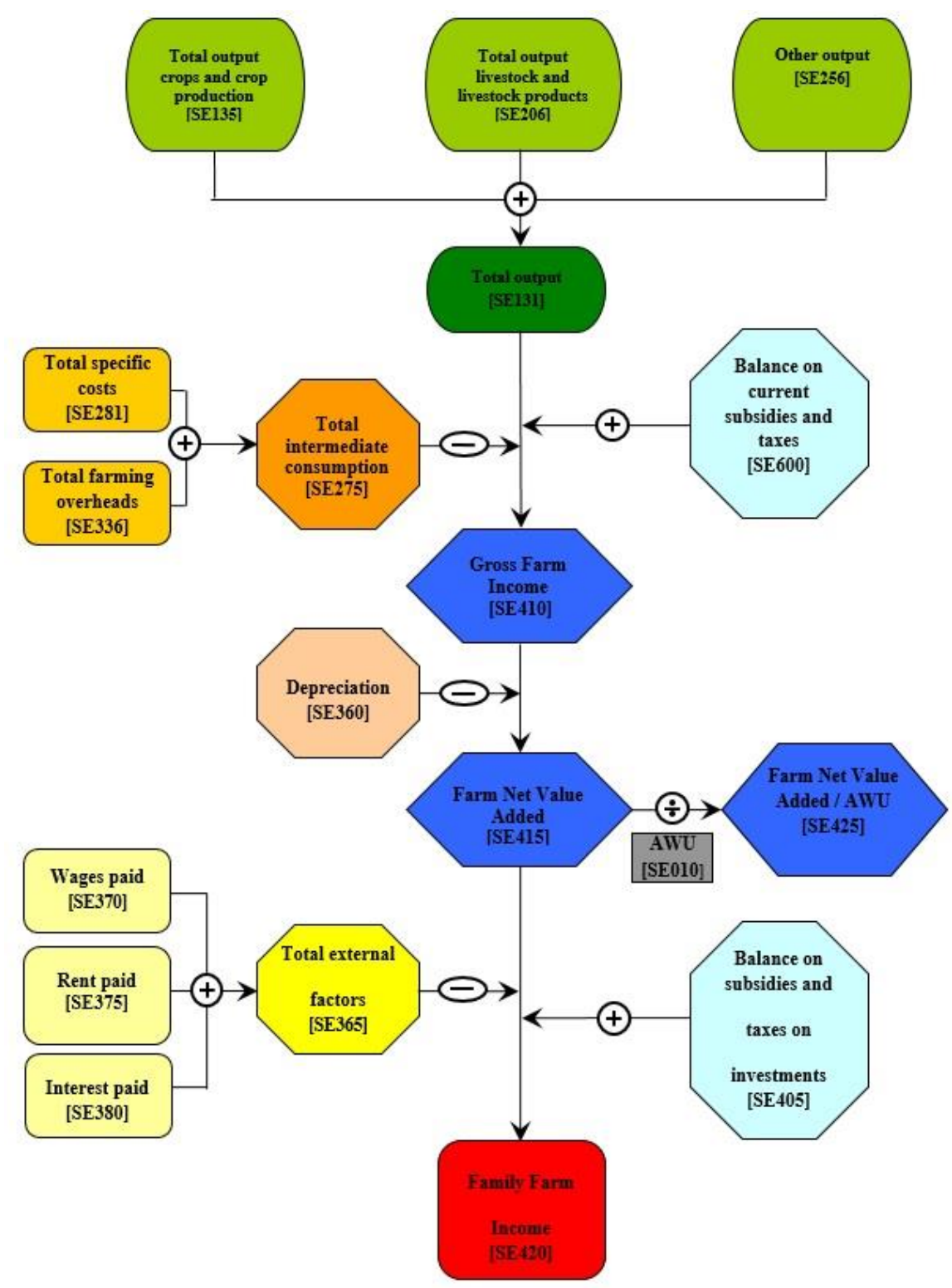

Diagram 1. The method for calculating farm income according to the FADN Source: FADN. 


\section{Methodology and theoretical basis}

Research hypotheses:

1) Currently, the income of farms in Poland is burdened with relatively (in relation to PIT rates) different tax rates.

2) As the economic strength of farms increases, the tax-to-income ratio decreases.

The research included the FADN farms in the years 2014-2018.

The study method will be a descriptive analysis, a financial analysis, a simulation method.

Diagram 1 illustrates the method for calculating farm income according to the FADN.

\section{Results and discussion}

Recognise the existing tax burden on farms. Propose new tax solutions.

\section{Assessment of taxation of farms}

Since 1947, Polish farms have been taxed in accordance with the principle consisting in the reduction of differential rent I. Until 1985, these principles were implemented by a land tax (Gorzelak, 1971, p. 5). As a basis for calculating its amount, estimated income was adopted; calculated per hectare of area. Its amount depended on the soil valuation class, type of utilised agricultural area, and location within the group of districts and within the economic zone. The land tax was generally calculated from 4 tax scales, which were also dependent on the location of land.

As from 1985, agricultural land, being a part of farms, has been taxed with the agricultural land tax (Juszczyk, 2019, pp. 142-146), (Podstawka, 1995, p. 53). It should be added that from 1985 to 1991 the agricultural tax had two forms. The first concerned the agricultural land tax. The second referred to special sections of agricultural production. In 1991 this form of agricultural tax ceased to apply, since the special sections were included in the PIT tax (Act of 26 July 1991 on Personal Income Tax).

The agricultural land tax, just like the previous land tax, has reduced the impact of differential rent I (Podstawka, 2005, p. 173). Therefore, it has equalised management conditions in agriculture. It is linear, and so it has not limited the development of farms and their expansion. In the case of this tax, 1 conversion hectare, which is a part of farms, is taxed with an equivalent of $2.5 \mathrm{q}$ rye. In addition, the agricultural tax, referring to the utilised agricultural area, i.e. to the production potential of farms, does not inhibit the increase in the intensity, productivity and profitability of farms. If an agricultural producer maximises potential, then the agricultural tax will reward him. This reward will consist in the fact that the unit of revenue or income will be burdened with the smaller amount of tax. Against a background of the presented peculiarities of the agricultural tax, some reflection does arise. Well, while just after World War II and in the 80s, the problem of agricultural policy was to support and improve the productivity of farms (Gorzelak, 1988, p. 17), currently this policy is focused on the sustainable development, climate protection, biodiversity, etc. In view of that, the structure of agricultural tax does not fit the current objectives of agricultural policy. There are many indications that it is time to replace it with the moderate progressive income tax.

In addition to the agricultural tax, farms owning forests are subject to the forest tax. Until 2003, there were two forms of this tax. The first concerned forests with a management plan, i.e., mainly the State Forests. The structure of this form of forest tax was similar to the agricultural land tax. On the other hand, the second type of agricultural tax, which concerned farmers' forests, was based on their area. For this basis, the rate of $0.3 \mathrm{q}$ rye from 1 ha of physical forest was referred. The results of these two forms of tax was that the State Forests were burdened with the forest tax about 2.5 times more when compared to farmers' forests. In those circumstances, the Forest Tax Act of 30 September 2002 standardised the taxation of forests (Act of 30 October 2002 on Forest Tax. Journal of Laws [Dz.U.] of 2002, No 200, item 1682). Currently, forests, regardless of their ownership, are taxed equally. The basis for the calculations is the area of a forest to which the rate of $0,220 \mathrm{~m}^{3}$ of the price of wood is referred. This amounts to about PLN 40 from 1 ha of physical forest (Podstawka, 2011, p. 197).

The third type of tax burdening farms is the property tax (Journal of Laws of 1991 No 9 item 31; Act of 12.01.1991 on local taxes and charges). In the case of farms, it applies only to residential buildings. The basis for its amount is the floor area of a residential building. The rates vary according to the decision of the municipal council. In 2020, the maximum rate set by the Minister of Finance was PLN 0.81 from $1 \mathrm{~m}^{2}$ floor space. The structure of the property tax does not allow to include the tax capacity of a taxpayer as, irrespective of the value of $1 \mathrm{~m}^{2}$ of a building or a land property, that tax rate is the same (Podstawka, 2017, p. 308). In this case, it would be worth considering the introduction of a cadastral tax, which is calculated from the value of a property (Dolata, 2013, p. 457). However, our experience related to the 1994 plan of introducing the cadastral tax is not good. As regards the amount of rates in this tax, a high degree of prudence would be advisable here. 


\section{Level of taxation of farms in the years 2014-2018}

This section of the study will present the economic results of farms maintaining FADN in the years 2014-2018. These data will allow us to compare the degree of the burdening of income of farms analysed with the existing taxes with the variant effects of the introduction of new taxes. The basic assumption adopted is that the burdening of farms with new taxes is not higher than the existing one. Considerations will be carried out according to the economic size of FADN farms. Tables 1 and 2 show the level of tax burden and its ratio to revenues and agricultural income.

Table 1. Burdening of farms with the agricultural tax and with other taxes

\begin{tabular}{|c|c|c|c|c|c|}
\hline \multirow{2}{*}{$\begin{array}{l}\text { Economic classifications } \\
\text { of FADN farms } \\
\text { (a) }\end{array}$} & \multicolumn{5}{|c|}{ Years } \\
\hline & 2014 & 2015 & 2016 & 2017 & 2018 \\
\hline \multicolumn{6}{|c|}{ Agricultural tax in PLN/farm } \\
\hline Very small (EUR 2-8 thous.) & 613 & 639 & 593 & 571 & 563 \\
\hline Small (EUR 8-25 thous.) & 1,080 & 1,079 & 1,055 & 999 & 1,005 \\
\hline Medium small (EUR 25-50 thous.) & 1,765 & 1,766 & 1,699 & 1,659 & 1,673 \\
\hline Medium large (EUR 50-100 thous.) & 2,880 & 2,946 & 2,796 & 2,697 & 2,720 \\
\hline Large (EUR 100-500 thous.) & 5,721 & 5,546 & 5,314 & 5,193 & 5,555 \\
\hline Very large (>EUR 500 thous.) & 7,010 & 4,602 & 5,476 & 6,965 & - \\
\hline \multicolumn{6}{|c|}{ Total taxes in PLN/farm } \\
\hline Very small (EUR 2-8 thous.) & 652 & 671 & 627 & 603 & 593 \\
\hline Small (EUR 8-25 thous.) & 1,122 & 1,119 & 1,097 & 1,042 & 1,046 \\
\hline Medium small (EUR 25-50 thous.) & 1,821 & 1,819 & 1,753 & 1,709 & 1,725 \\
\hline Medium large (EUR 50-100 thous.) & 2,943 & 3,008 & 2,852 & 2,756 & 2,774 \\
\hline Large (EUR 100-500 thous.) & 5,826 & 5,700 & 5,423 & 5,288 & 5,635 \\
\hline Very large (>EUR 500 thous.) & 7,757 & 5,051 & 7,488 & 7,533 & - \\
\hline
\end{tabular}

(a) Bocian, M., Cholewa, I., Tarasiuk, R. (2017). Standard Output "2013" Coefficients for the Purposes of the Community Typology for Agricultural Holdings. Warsaw: IAFE-NRI, 43-55

Source: FADN data in the years 2014-2018.

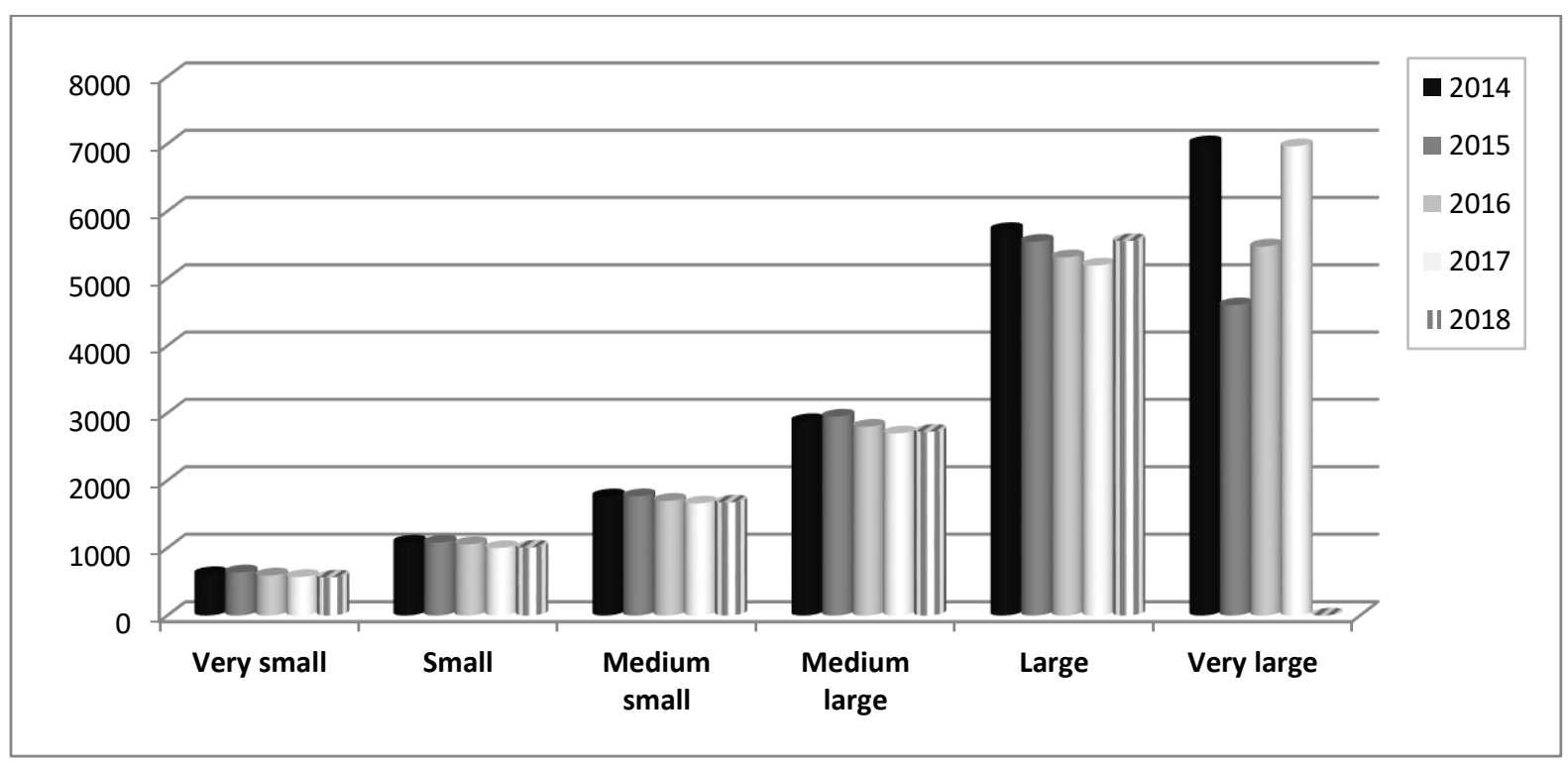

Figure 1. Agricultural tax in PLN/farm in the years 2014-2018

Source: FADN data in the years 2014-2018.

The information provided in Table 1 indicates the

reasonable principle that the burden of agricultural tax increases as the economic strength of farms increases. This results from the increase in 
the area of farms as their economic strength improves. According to FADN data, in the years analysed, very small farms had an area of about 8 ha of UAA, small farms - about 15 ha, medium small farms - about 27 ha, medium large farms about 45 ha, large farms - about 83 ha.

The information provided in Table 1 indicates that agricultural tax accounted for more than $90 \%$ of the tax burden of farms analysed. The remaining burden, due to the forest tax and the property tax, had a small share in the burden structure. It is interesting to assess the ratio of the tax burden of farms analysed to the income they achieve. As it has been mentioned, the applicable information is provided in Table 2.

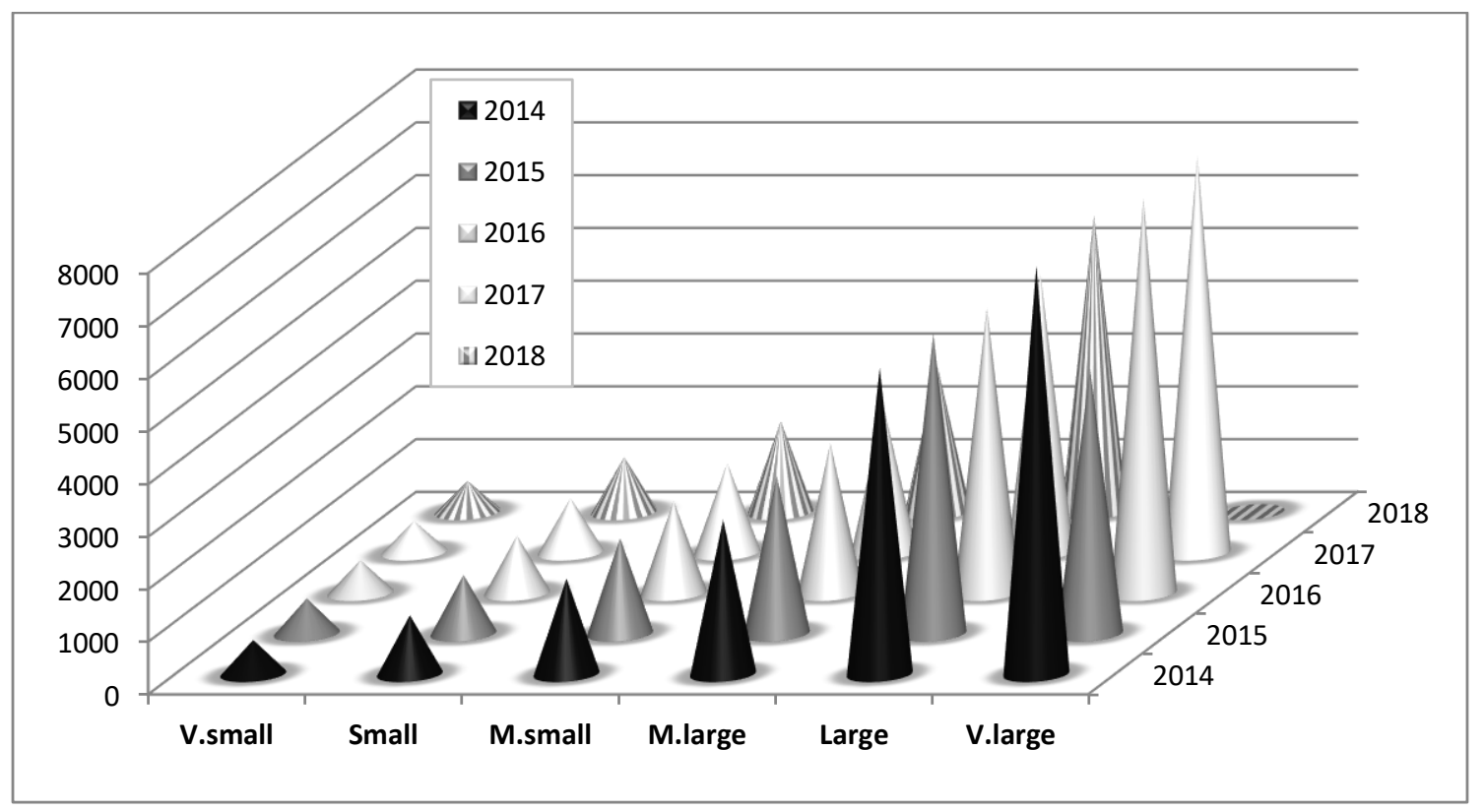

Figure 2. Total taxes in PLN/farm in the years 2014-2018

Source: FADN data in the years 2014-2018.

Table 2. Ratio of total tax burden of farms to their income

\begin{tabular}{|c|c|c|c|c|c|}
\hline \multirow{2}{*}{ Economic classes of FADN farms } & \multicolumn{5}{|c|}{ Years } \\
\hline & 2014 & 2015 & 2016 & 2017 & 2018 \\
\hline \multicolumn{6}{|c|}{ Agricultural income without subsidies in PLN/farm } \\
\hline Very small (EUR 2-8 thous.) & $-3,052$ & $-2,788$ & $-1,815$ & $-1,817$ & $-3,227$ \\
\hline Small (EUR 8-25 thous.) & 3,747 & 3,864 & 3,001 & 7,075 & 1,560 \\
\hline Medium small (EUR 25-50 thous.) & 25,716 & 21,884 & 23,190 & 37,856 & 28,333 \\
\hline Medium large (EUR 50-100 thous.) & 65,539 & 46,912 & 51,742 & 87,710 & 68,821 \\
\hline Large (EUR 100-500 thous.) & 201,350 & 170,083 & 191,404 & 208,416 & 191,924 \\
\hline Very large (>EUR 500 thous.) & 479,173 & 768,479 & 677,508 & 574,559 & - \\
\hline \multicolumn{6}{|c|}{ Share of total tax burden on farm income without subsidies in $\%$} \\
\hline Very small (EUR 2-8 thous.) & - & - & - & - & - \\
\hline Small (EUR 8-25 thous.) & 29.9 & 28.96 & 36.55 & 14.73 & 67.05 \\
\hline Medium small (EUR 25-50 thous.) & 7.08 & 8.31 & 7.56 & 4.51 & 6.09 \\
\hline Medium large (EUR 50-100 thous.) & 4.50 & 6.41 & 5.51 & 3.14 & 4.03 \\
\hline Large (EUR 100-500 thous.) & 2.89 & 3.35 & 2.83 & 2.54 & 2.94 \\
\hline Very large (>EUR 500 thous.) & 1.62 & 0.97 & 1.11 & 1.31 & - \\
\hline
\end{tabular}




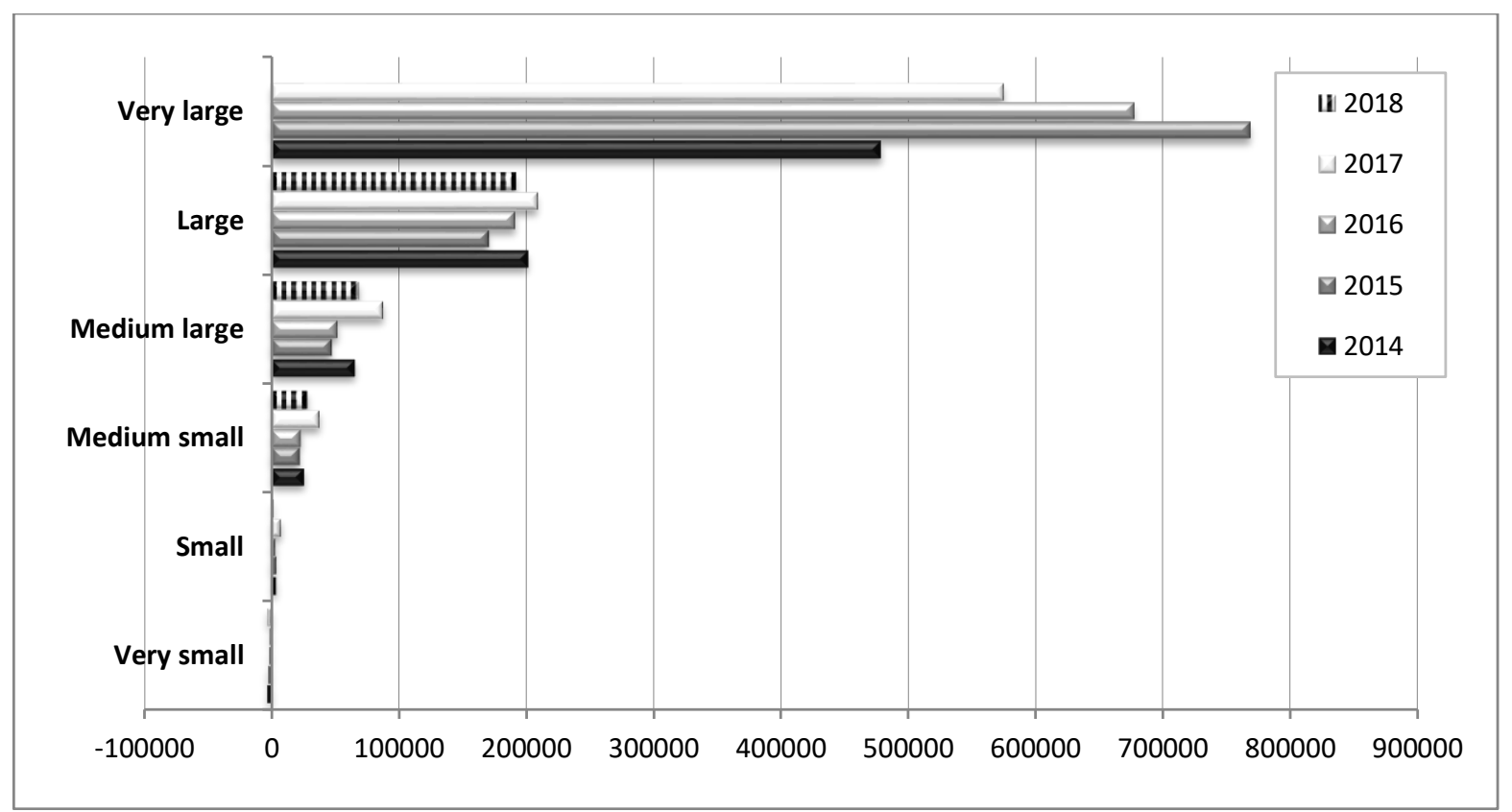

Figure 3. Agricultural income without subsidies in PLN/farm in the years 2014-2018 Source: FADN data in the years 2014-2018.

According to the figures in Table 2, the burdening of FADN farm incomes with taxes is diverse. This burden is the highest among small farms and ranges from $14.73 \%$ to $67.05 \%$ : against a background of other economic groups of farms, it is the highest. As the economic situation of farms improves, the total tax burden in relation to their income decreases. This is the effect of the area, which increases, as the economic strength of farms increases and the principles of the linear dimension of the agricultural tax and its share of more than $90 \%$ in the total tax burden of farms analysed. The most favourable situation is that of very large farms. Among them, the ratios of tax burden to income are about $1 \%$.

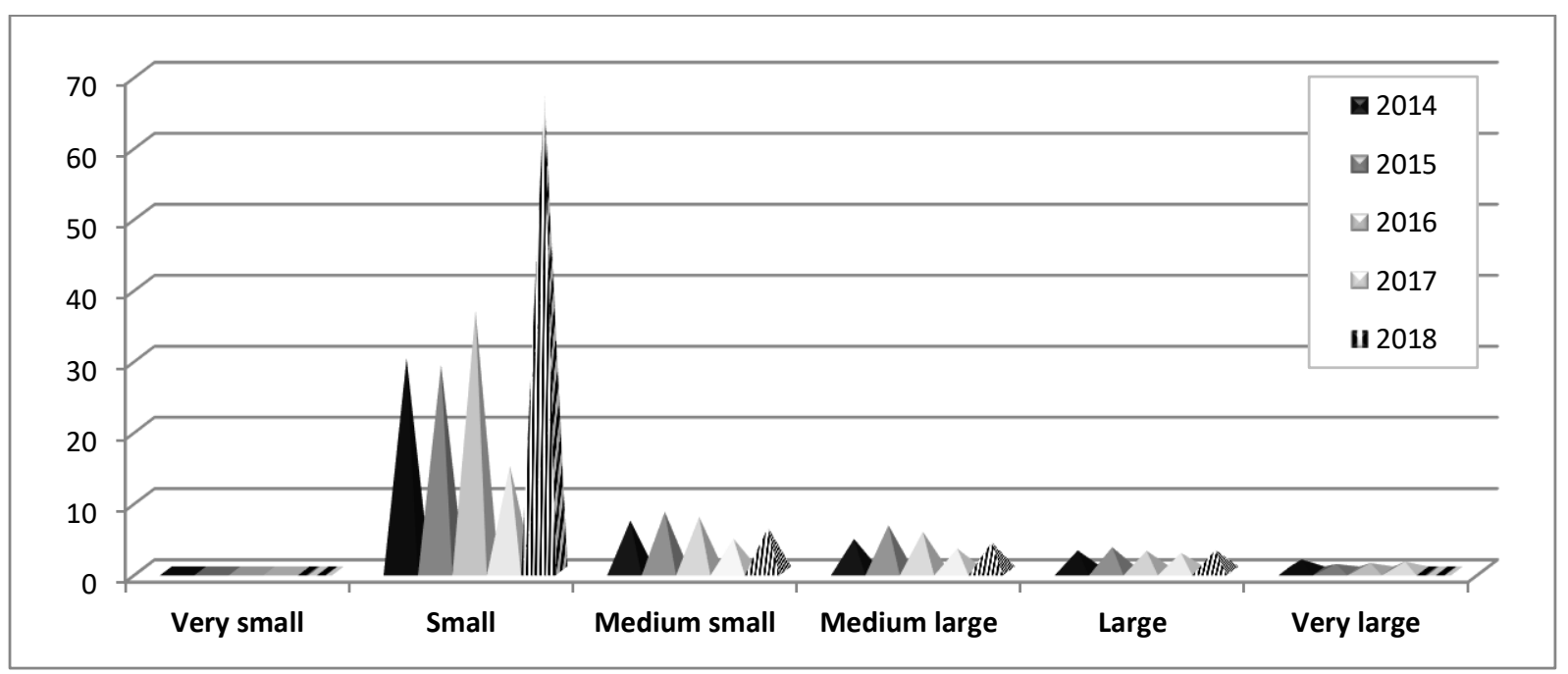

Figure 4. Share of total tax burden in farm income without subsidies in \% Source: FADN data in the years 2014-2018.

Over the years analysed, we may see that the trends when it comes to the share of total tax burden in income, among economic groups of farms surveyed, have been maintained.
An important problem, from the point of view of changes in the taxation of farms, is the assessment of the ratio of total tax burden to their income with EU subsidies. The relevant information is provided in Table 3. 
M.G. Podstawka, DILEMMAS RELATED TO POTENTIAL CHANGES IN THE TAXATION OF FARMS, Zeszyty Naukowe Uniwersytetu Przyrodniczo-Humanistycznego w Siedlcach Nr 124, Seria: Administracja i Zarządzanie (51) 2020

Table 3. Income of FADN farms with subsidies and the share of total tax burden in this income

\begin{tabular}{|c|c|c|c|c|c|}
\hline \multirow{2}{*}{ Economic classes of FADN farms } & \multicolumn{5}{|c|}{ Years } \\
\hline & 2014 & 2015 & 2016 & 2017 & 2018 \\
\hline \multicolumn{6}{|c|}{ Income with subsidies in PLN/farm } \\
\hline Very small (EUR 2-8 thous.) & 7,922 & 7,880 & 8,707 & 9,472 & 8,778 \\
\hline Small (EUR 8-25 thous.) & 24,448 & 25,880 & 25,760 & 31,130 & 26,606 \\
\hline Medium small (EUR 25-50 thous.) & 62,345 & 60,504 & 65,080 & 80,201 & 73,608 \\
\hline Medium large (EUR 50-100 thous.) & 127,562 & 106,092 & 116,748 & 151,258 & 137,974 \\
\hline Large (EUR 100-500 thous.) & 320,976 & 264,434 & 288,508 & 313,299 & 302,796 \\
\hline Very large (>EUR 500 thous.) & 603,646 & 836,854 & 756,265 & 724,995 & - \\
\hline \multicolumn{6}{|c|}{ Ratios of total tax burden to income with subsidies in \% } \\
\hline Very small (EUR 2-8 thous.) & 8.23 & 8.51 & 7.20 & 6.37 & 6.76 \\
\hline Small (EUR 8-25 thous.) & 4.59 & 4.32 & 4.26 & 3.35 & 3.93 \\
\hline Medium small (EUR 25-50 thous.) & 2.92 & 3.00 & 2.69 & 2.13 & 2.34 \\
\hline Medium large (EUR 50-100 thous.) & 2.31 & 2.83 & 2.44 & 1.82 & 2.01 \\
\hline Large (EUR 100-500 thous.) & 1.82 & 2.16 & 1.88 & 1.69 & 1.86 \\
\hline Very large (>EUR 500 thous.) & 1.29 & 0.60 & 0.99 & 1.04 & - \\
\hline
\end{tabular}

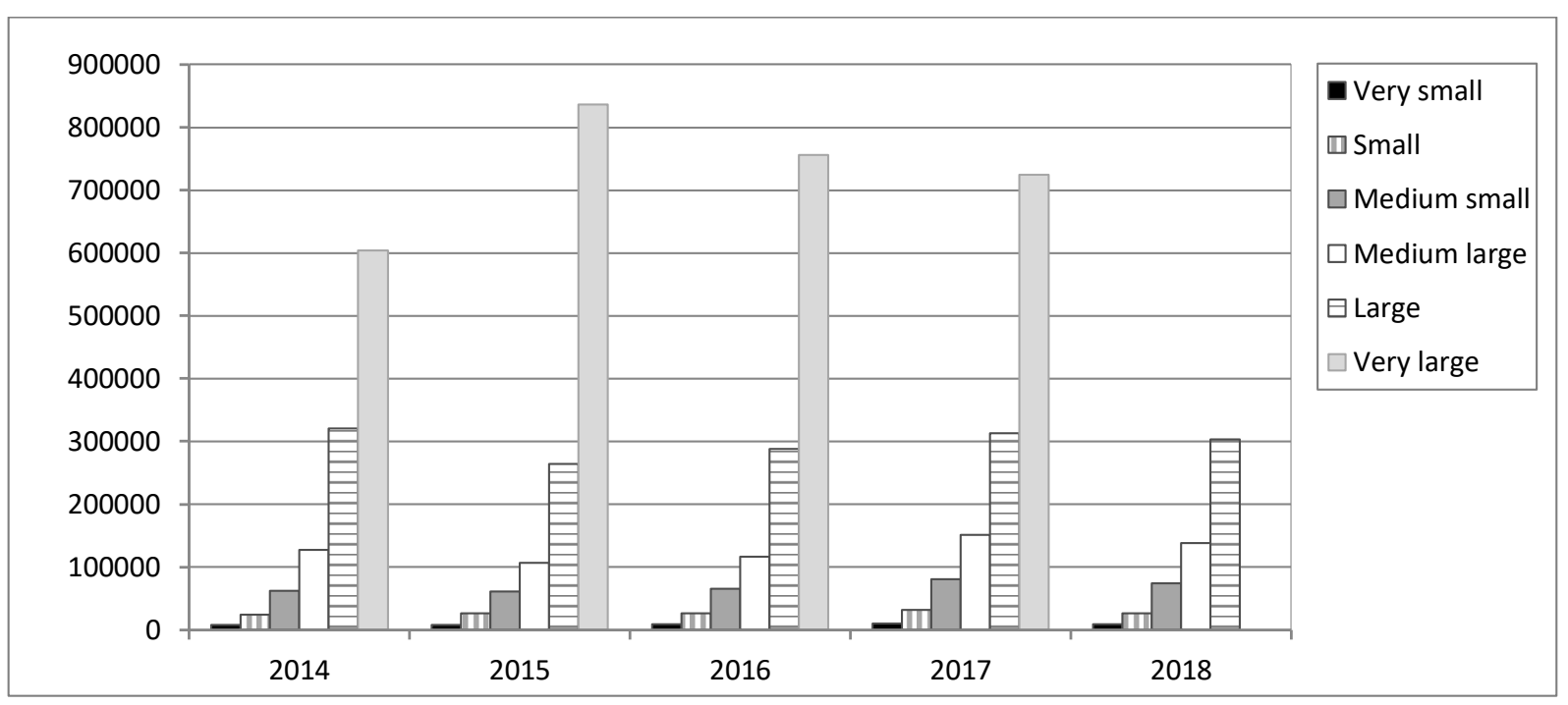

Figure 5. Income with subsidies in PLN/farm

Source: FADN data in the years 2014-2018.

According to the information provided in Table 3, the share of total tax burden in farm income with subsidies is lower than in the case of that share of income from agricultural activities alone. This is understandable and logical; however, as the economic strength of farms increases, this reduction weakens. It is the largest for the economically weakest farms (very small). This means that, among them, EU subsidies represent the largest share in the structure of their income when compared to economically stronger farms. On these farms, the total tax burden in relation to their income with subsidies is nominal.

From the point of view of new solutions in the taxation of farms, it is important to assess the share of agricultural tax and total tax burden for farms in the value of their commodity production. The relevant information is provided in the following Table 4. 


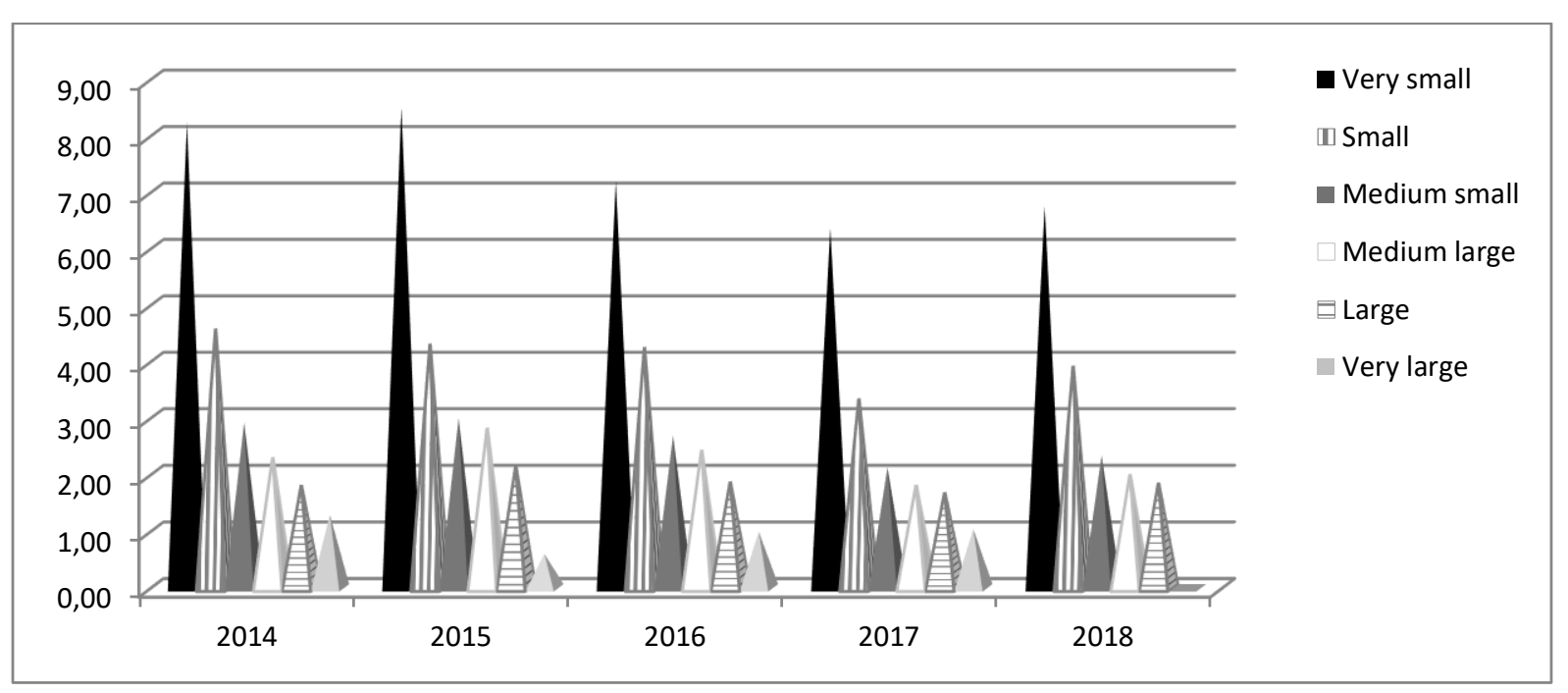

Figure 6. Ratios of total tax burden to income with subsidies in \% Source: FADN data in the years 2014-2018.

Table 4. Share of agricultural tax and total tax burden for farms in their sales revenues

\begin{tabular}{|c|c|c|c|c|c|}
\hline \multirow{2}{*}{ Economic classes of FADN farms } & \multicolumn{5}{|c|}{ Years } \\
\hline & 2014 & 2015 & 2016 & 2017 & 2018 \\
\hline \multicolumn{6}{|c|}{ Sales revenues per farm in PLN } \\
\hline Very small (EUR 2-8 thous.) & 23,599 & 24,633 & 23,521 & 25,771 & 27,779 \\
\hline Small (EUR 8-25 thous.) & 60,917 & 61,815 & 60,358 & 65,859 & 63,156 \\
\hline Medium small (EUR 25-50 thous.) & 153,963 & 153,252 & 148,117 & 161,711 & 161,562 \\
\hline Medium large (EUR 50-100 thous.) & 340,747 & 312,222 & 307,986 & 339,949 & 340,521 \\
\hline Large (EUR 100-500 thous.) & $1,166,437$ & $1,099,465$ & $1,147,995$ & $1,001,845$ & $1,018,019$ \\
\hline Very large (>EUR 500 thous.) & $3,735,304$ & $4,764,325$ & $4,703,358$ & $4,207,910$ & r \\
\hline \multicolumn{6}{|c|}{ Share of agricultural tax in sales revenues in $\%$} \\
\hline Very small (EUR 2-8 thous.) & 2.60 & 2.59 & 2.52 & 2.21 & 2.03 \\
\hline Small (EUR 8-25 thous.) & 1.77 & 1.74 & 1.75 & 1.52 & 1.59 \\
\hline Medium small (EUR $25-50$ thous.) & 1.15 & 1.15 & 1.15 & 1.02 & 1.04 \\
\hline Medium large (EUR 50-100 thous.) & 0.85 & 0.94 & 0.91 & 0.79 & 0.80 \\
\hline Large (EUR 100-500 thous.) & 0.49 & 0.50 & 0.46 & 0.52 & 0.55 \\
\hline Very large (>EUR 500 thous.) & 0.19 & 0.10 & 0.12 & 0.17 & . \\
\hline \multicolumn{6}{|c|}{ Share of total tax burden for farms in sales revenues in $\%$} \\
\hline Very small (EUR 2-8 thous.) & 2.76 & 2.72 & 2.66 & 2.34 & 2.14 \\
\hline Small (EUR 8-25 thous.) & 1.84 & 1.81 & 1.82 & 1.58 & 1.66 \\
\hline Medium small (EUR 25-50 thous.) & 1.18 & 1.19 & 1.18 & 1.06 & 1.07 \\
\hline Medium large (EUR 50-100 thous.) & 0.86 & 0.96 & 0.93 & 0.81 & 0.81 \\
\hline Large (EUR 100-500 thous.) & 0.50 & 0.52 & 0.47 & 0.53 & 0.55 \\
\hline Very large (>EUR 500 thous.) & 0.21 & 0.11 & 0.10 & 0.18 & r \\
\hline
\end{tabular}




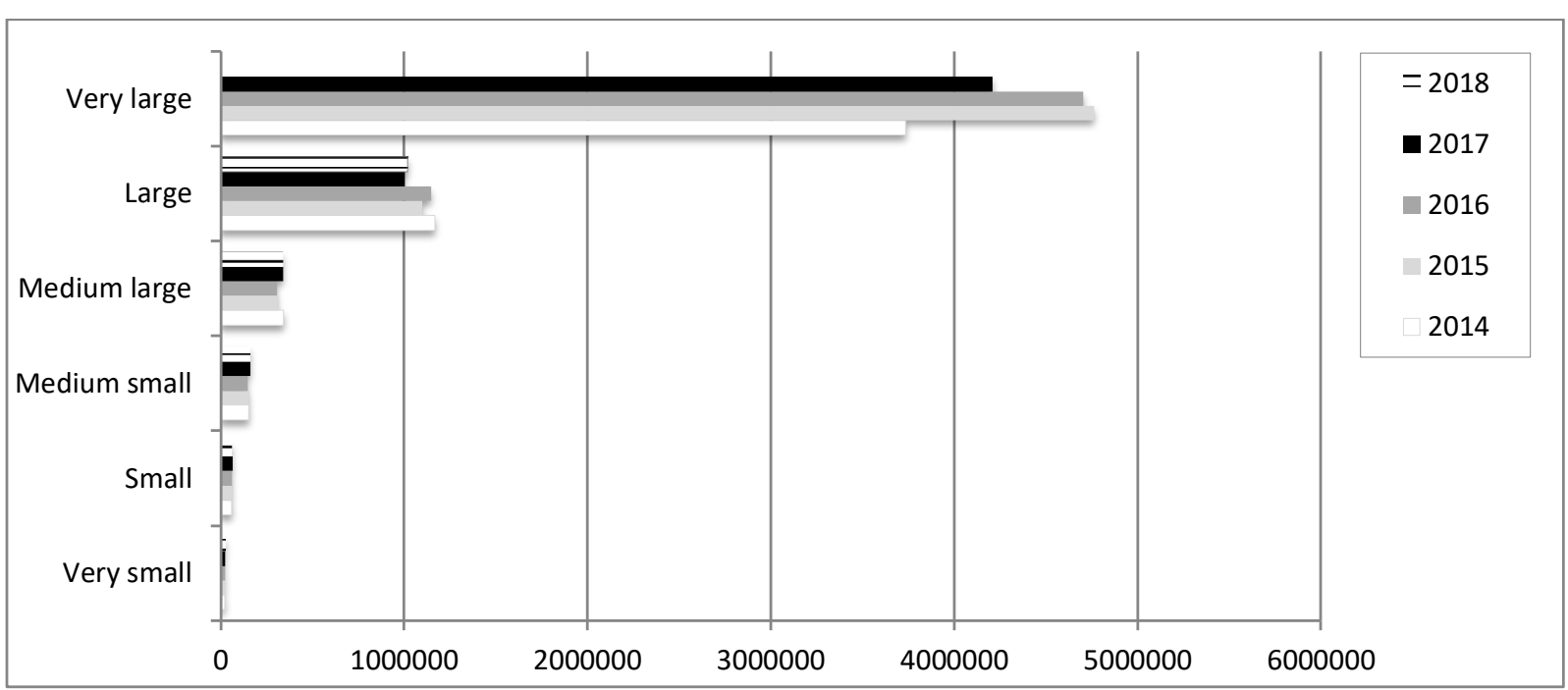

Figure 7. Sales revenues per farm in PLN Source: FADN data in the years 2014-2018.

It is apparent from the information contained in Table 4 that the share of agricultural tax in sales revenues of FADN farms is nominal. As their economic strength increases, the share of this tax in revenues decreases. This attests to the increase in the efficiency of management and the use of production scale effects on economically stronger farms. The ratios of the share of total tax burden in sales revenues among farms analysed are similar.

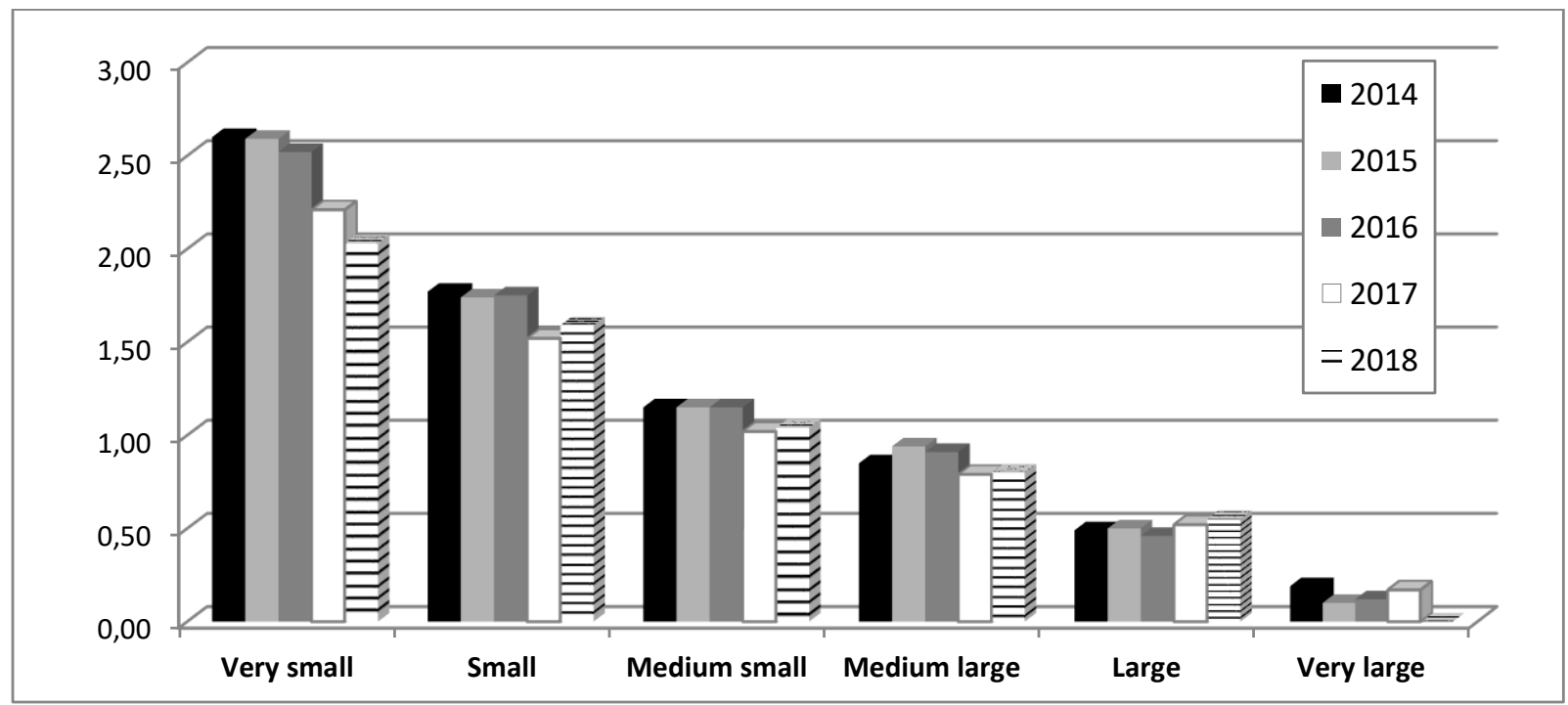

Figure 8. Share of agricultural tax in sales revenues in \% Source: FADN data in the years 2014-2018. 


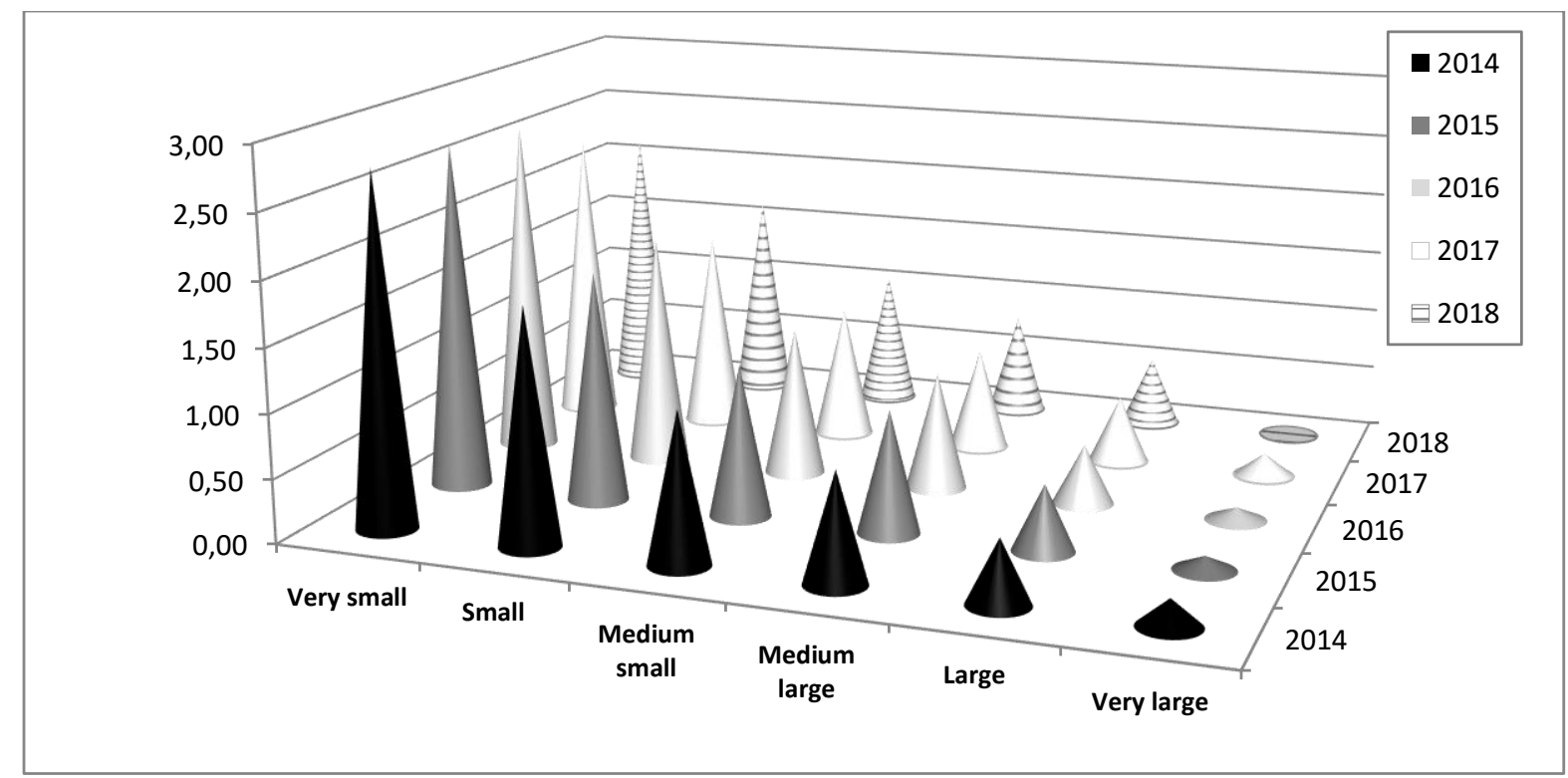

Figure 9. Share of total tax burden for farms in sales revenues in \% Source: FADN data in the years 2014-2018.

\section{Taxation of farms in the future}

Changes in the taxation of income from sources of agricultural activities seem to be inevitable. This is about the burdening of this income with the PIT tax. However, before it takes place, it is necessary to calculate this income.

A number of streamlined measures aimed at recording economic events on farms, due to the fact that they receive all kinds of subsidies, are being gradually introduced by the Ministry of Agriculture and Rural Development. These same measures have the transparency of the financial situation of farms. The greatest changes in this respect pertain to the paying of compensation for drought. It seems that in the future such payments should be abandoned. In the market economy, under conditions of reduced harvest, there is compensation in the form of price rises. Therefore, it may happen that the reduced harvest does not need to negatively impact on a farm's income. For this and for many other reasons, it is time to make a reliable assessment of the income situation of farms. It is not just about public expenses, which should be organised in the event of losses in farm income. The more important issue is that the calculation of income is essential for the making of managerial decisions on the farm; in order to optimise the structure of production, costs, etc. (Czyżewski, 2017, p. 86).

As regards matters related to possible changes in the taxation of farms, it should be stressed that they should not increase their fiscal burden. When setting income tax rates, "far-reaching restraint" must be maintained. Such solutions have been adopted in many EU countries when it comes to the taxation of farm income (Czyżewski, 2016). According to the calculations carried out, the rates of possible income tax relating to farm income only cannot be higher than a few percent (around 5\%). If income tax were to replace all taxes paid by farmers so far, its rate could also not be higher than around $5 \%$. We can imagine that the tax will apply to income from agricultural activities. If it happened, the rate of this tax should not be higher than $1 \%$ to $1.5 \%$.

When including subsidies in income and taxing them with a single tax, the rate of that same tax should not exceed $2-3 \%$. However, the EU would probably not agree to this solution

This study has met its objectives. The level of income taxation with existing property taxes on agricultural land in Poland was recognised here. The results of the analysis presented in the study can be used in the shaping of future tax policy for Polish agriculture.

By taxing income, it should be noted that in the initial phase the level to which it is burdened with the new tax should not exceed the current taxation of agricultural land tax, forestry tax and property tax. This study has contained such information.

\section{Conclusions}

1) Imposition of agricultural tax and other taxes on income of farms is nominal among those which are classified as medium small (7\%), medium large $(5 \%)$, large $(3 \%)$, very large (ca. 1\%). 
2) Small farms are subject to relatively higher taxes. The tax rate in this case is ca. $30 \%$. Very small farms do not generate income.

3) There is a relative reduction in the tax burden on farms' revenues. In the case of very small farms, it represents ca. $2.5 \%$. As far as small and medium small farms are concerned, it amounts to $1.5 \%$. In the case of medium large and large farms, it accounts for $0.9 \%$ and $0.5 \%$, respectively. Very large farms have a tax-to-revenue ratio of ca. $0.15 \%$.

4) When introducing income tax, its rate should amount to about $5 \%$. However, the revenue tax rate should be ca. $1 \%$, maintaining the current degree of fiscal burden on farms.

\section{References}

Bocian, M., Cholewa, I., Tarasiuk, R. (2017). Współczynniki Standardowej Produkcji „2013” dla celów Wspólnotowej Typologii Gospodarstw Rolnych. Warszawa: Wydawnictwo IERiGŻ-PIB, 43-55.

Czyżewski, B. (2017). Kierat rynkowy w europejskim rolnictwie. Warszawa: Wydawnictwo Naukowe PWN, 86.

Dolata, S. (2013). Podstawy wiedzy o polskim systemie podatkowym. Warszawa: Wydawnictwo 3 Lex \& Wolters Kluwer Business, 457.

Floriańczyk, Z., Osuch, D., Płonka, R. (2018). Wyniki Standardowe 2017 uzyskane przez gospodarstwa rolne uczestniczące w Polskim FADN Część I. Wyniki Standardowe. Warszawa: Wydawnictwo IERiGŻ-PIB.

Gorzelak, E. (1971). Polityka finansowa państwa wobec indywidualnej gospodarki chłopskiej. Wieś Współczesna Nr 3, 5.

Gorzelak, E. (red.). (1988). Polityka agrarna PRL. Warszawa: Wydawnictwo SGPiS, 17.

Juszczyk, S. (red.). (2019). Specyfikacja opodatkowania gospodarstw rolnych. Finanse agrobiznesu. Warszawa: Wydawnictwo Naukowe PWN, 142-146.
Podstawka, M. (1995). Opodatkowanie rolnictwa i perspektywy jego zmian w Polsce. Warszawa: Wydawnictwo SGGW, 53.

Podstawka, M. (2005). Podstawy finansów. Warszawa: Wydawnictwo SGGW, 173.

Podstawka, M. (red.). (2017). Finanse. Warszawa: Wydawnictwo PWN, 308.

Podstawka, M. (2011). Podstawy finansów. Warszawa: Wydawnictwo SGGW, 197.

Podstawka, M. (red.) (2016). Systems of taxation of agriculture in certain EU countries. Universal and distinctive features and an evaluation. Czyżewski, B. Political rents of European farmers in the sustainable development paradigm. Internarional, national adn regional perspective. Warszawa: Wydawnictwo PWN.

Ricardo, D. (1913). Zasady ekonomii politycznej i opodatkowania. London G. Bell \& sons, Ltd, ed. 2, 125.

\section{Legal acts:}

Ustawa z 12 stycznia 1991 r. o podatkach i opłatach lokalnych. Dz.U. z 1991 r., nr 9, poz. 31.

Ustawa z 30 października 2002 r. o podatku leśnym. Dz.U. z 2002 r., nr 200, poz. 1682.

Ustawa z 26 lipca 1991 r. o podatku dochodowym od osób fizycznych. 